\title{
Risks associated to different methods of increasing pregnancy rate of cows in cow-calf systems
}

\section{Tamara Esteves de Oliveira' ${ }^{1}$ iD, Júlio Otávio Jardim Barcellos ${ }^{1,2^{*}}$ iD, Jack Whittier ${ }^{3}$, Odilene de Souza Teixeira' ${ }^{1}$ (D), David Santos de Freitas ${ }^{4}$ ID, Ricardo Pedroso Oaigen ${ }^{5}$ (iD, Matheus Dhein Dill ${ }^{6}$ iD, Concepta McManus ${ }^{7}$ (iD}

\footnotetext{
1 Universidade Federal do Rio Grande do Sul, Núcleo de Estudos em Sistemas de Produção de Bovinos de Corte e Cadeia Produtiva, Porto Alegre, RS, Brasil.

2 Universidade Federal do Rio Grande do Sul, Programa de Pós-graduação em Zootecnia, Porto Alegre, RS, Brasil.

${ }^{3}$ University of Nebraska, Panhandle Research and Extension Center, Scottsbluff, Nebraska, United States of America.

${ }^{4}$ Universidade do Vale do Rio dos Sinos, Programa de Pós-graduação em Biologia, São Leopoldo, RS, Brasil.

${ }^{5}$ Universidade Federal do Pampa, Programa de Pós-graduação em Ciência Animal, Uruguaiana, RS, Brasil.

${ }^{6}$ Universidade Federal Rural de Pernambuco, Garanhuns, PE, Brasil.

${ }^{7}$ Universidade de Brasília, Brasilia, DF, Brasil.
}

\begin{abstract}
This study assessed the risks of different management practices to increase pregnancy rate in beef cow-calf systems, aiming at assisting decision-making. The perception of 18 experts on animal sciences regarding the risks of 32 nutritional, breeding, and general management practices applied to increase pregnancy rate were evaluated through questionnaires. The experts were selected by a non-probability sampling of researchers on veterinary and animal sciences. In addition, five farmers and eight technical consultants were also selected. The questionnaire was applied during a face-to-face meeting. The risk of each practice was assessed according to four factors, namely, cost, technical knowledge, operational complexity, and flexibility, and an equation was developed to calculate this risk. The applied method allowed to determine the risk of each practice, obtaining results similar to those previously perceived by the experts. Operational complexity and cost had greater influence on the estimated risks compared with the other factors. Moreover, the increase of one unit in operational complexity and cost increased the perceived risk and the estimated risk scores in 0.43 and 0.28 points, respectively. Overall, the application of general management practices presented lower risk score compared with nutritional and breeding practices, which were not different from which other. Equations to estimate the risks of farm managers should routinely apply management practices to increase the efficiency of cow-calf production systems.
\end{abstract}

Key Words: animal production, beef cattle, breeding, nutrition, production cost

\section{Introduction}

Technologies in the last three decades changed Brazilian beef cattle, increasing its productivity and taking the country to a prominent position in the international market (Dill et al., 2015a). However, the adoption of new technologies takes a long time due to the complex environment managers work on (Weisenfeld and Ott, 2011) and the low profitability of beef cattle systems, particularly with the economic challenges faced by cow-calf systems (Oaigen et al., 2008).

Received: March 6, 2018

Accepted: July 31, 2018

*Corresponding author: julio.barcellos@ufrgs.br

Copyright (C) 2018 Sociedade Brasileira de Zootecnia. This is an Open Access article distributed under the terms of the Creative Commons Attribution License (http://creativecommons.org/licenses/by/4.0/), which permits unrestricted use, distribution, and reproduction in any medium, provided the original work is properly cited.
In addition, these systems are usually based on grazing on low-quality pastures, resulting in low reproductive efficiency with use of large tracts of land with little or no subdivision and supplementation (Dick et al., 2015). Thus, reproductive efficiency, which can be measured by the pregnancy rate (Burns et al., 2010), is relatively low in Brazil, around 60\% (ANUALPEC, 2015).

In this context, the use of technologies should be implemented to optimize the reproductive efficiency, which include the nutritional support for cows (e.g., supplementation, pasture management), management practices (e.g., early weaning, sanitary planning), and reproductive strategies (e.g., fixed-time artificial insemination, embryo transfer). However, the risk of failure is always present, and the effects of technologies and their magnitude are influenced by human, natural, and financial resources. Risk is, as a variable that can be measured, a quantifiable uncertainty (Knight, 1921), and although risk analyzes are more reliable, they are based on more complex 
methods and require in-depth evaluations of parameters that are frequently not under control of farmers (Cooper and Schindler, 2014).

This complexity is more concerning in agricultural decision-making, since these firms are affected by many factors. For instance, the adoption of agricultural technologies is influenced by individual, socioeconomic, and cultural factors, as well as by specific characteristics of the technologies, which may provide important perceptions of their risks. Consequently, simple decision support tools are not available, and technology adoption is solely based on the perception of farm managers.

Therefore, this study aimed to assess the risk of management practices to increase pregnancy rate in cowcalf systems, based on the perception of experts and propose a simple and practical model to assist decision-making in beef production systems.

\section{Material and Methods}

A questionnaire on management practices on the main technologies to increase pregnancy rate in cow-calf systems was elaborated and applied in Southern Region of Brazil. The technologies and their categories were determined and included in the questionnaire according to a literature review and validated by the experts during the pre-test.

At first, the questionnaire was applied in a pre-test to a select group of seven experts, who considered the technologies evaluated in relation to the categories of technology to which they belong: nutritional, breeding, or management practices. During this stage, corrections were made to include or to withdraw technologies, as well as to reallocate them to other categories, according to the evaluation of the experts. The categorization was used to facilitate the comparison of the types of technologies and to future generalization to other technologies not considered in this study.

The final questionnaire was applied to 18 experts selected using non-probability sampling, according to their relevance on pregnancy rate publications and discussions regarding cow-calf management, as well as their availability to participate in the interviews. The respondents included researchers on veterinary and animal sciences working in public institutions both in research and extension, including specialists in herd statistics, risk analysis, beef cattle nutrition, breeding, animal welfare, and production system management.

In addition, five farmers and eight technical consultants were also invited to answer the questionnaire. The farmers included in the study obtained performance indexes above regional averages and applied at least 10 of the practices included in the questionnaire.

Technical meetings with farmers and experts were carried out to explain the definition of each practice and the guidelines for completing the questionnaire. The survey was applied during a face-to-face meeting and included 32 nutritional, breeding, and general management practices that affect the pregnancy rate in cow-calf systems (Table 1).

These techniques can be classified as routine practices, which are commonly applied in beef cattle farms in southern Brazil, or innovative technologies, which are those used on a few pioneering farms. All practices were analyzed according to four factors that compose the risk, defined in this study as the likelihood of management practice not yielding the expected results, referred as the probability of failure.

The respondents assigned absolute scores in a fivelevel Likert scale $(1=$ very low, 2 = low, $3=$ average, $4=$ high, 5 = very high) for each practice according to risk factor (cost, necessary knowledge, operational complexity, and flexibility) (Table 2). Since risk can be understood as the uncertainty effect on the objectives of the firm, and therefore, is neither positive nor negative (Purdy, 2010), the estimated risk was evaluated as the probability that the technology will not generate the expected response, which in the present study, is pregnancy rate.

The risks of management practice were compared according to type (process-related vs. input-dependent) and function (management, nutrition, or breeding). Inputdependent practices are those that require a standard product, usually commercially available to all farmers (e.g., vaccines, diets, feed supplements, hormones, etc.). Processrelated management practices are related to organizational strategies, organization of animal categories, feeding practices, management techniques, and tacit knowledge applied to the production system that do not essentially depend on inputs (Johnson et al., 2010; Dill et al., 2015b).

The questionnaire responses were inputted in worksheets (Microsoft Excel 2010®), and the effects of the factors (cost, knowledge, operational complexity, and flexibility) on the estimated risk were analyzed by multiple linear regression.

Differences among the average estimated risks of each factor were analyzed by the Mann-Whitney's and KruskalWallis test. The scores estimated by the experts for each factor in each management practice were compared using Friedman's analysis of variance. All data were analyzed using the Biostat software 5.3 (Ayres et al., 2007), considering a 0.05 significance level. 
Table 1 - Description of nutritional, general management, and breeding practices

\begin{tabular}{ll}
\hline Practice & Definition \\
\hline
\end{tabular}

Nutritional management

Creep-feeding

Creep-grazing

Flushing

Pasture irrigation

Improved pastures during postpartum period Improved pastures pre-calving

Hay supplementation

Cow supplementation post-calving

Cow supplementation pre-calving

Mineral supplementation

Early weaning at 45-60 days

Early weaning at 60-90 days

Early weaning at 90-120 days

Calf removal

Stocking rate adjusted according to BCS

Cow grouping by age

Cow grouping by calving date

Health plan

Pregnancy diagnosis

Culling of empty cows

First mating at 18 months

Biostimulation (cows)

Breeding soundness examination of bulls

Artificial insemination

Fixed-time artificial insemination

Mating monitoring

Estrus synchronization

Superovulation and embryo transfer

Employee training in calving assistance
Feed supplied ad libitum exclusively to suckling calves, not accessible to the dam High-quality forage supplied exclusively to calves, not accessible to the dams Supply of an energy-rich diet to cows for 30 days before mating Adoption of irrigation practices to forage paddocks

Lactating cows grazing on improved pastures for 60 days post-calving

Pregnant cows grazing on improved pastures for 60 days pre-calving

Supply of low-quality hay to dams for 90 days pre-calving

Supply of energy supplements to lactating cows for 45 days post-calving

Supply of energy supplements to pregnant cows for 45 days pre-calving

Supply of macro and trace mineral supplements during all production periods

\section{General management}

Calves weaned between 45 and 60 days of age

Calves weaned between 60 and 90 days of age

Calves weaned between 90 and 120 days of age

Calf separation from the dam for 24-48 $\mathrm{h}$

Pasture stocking rate adjusted according to the body condition score (BCS) of cows

Breeding management of cows grouped according to calving order

Cows grouped according to calving date

Compulsory (brucellosis, foot-and-mouth disease) and preventive (leptospirosis) vaccines, drenching, and dipping schedules

Pregnancy diagnosis by rectal palpation (45 days) or ultrasound (30 days)

Culling of all empty cows from the herd after breeding season

\section{Breeding management}

Heifers mated at 18 months of age

Use of androgenized females or of males for estrous stimulation

Evaluation of the breeding soundness of bulls, including sperm quality

Assisted-reproduction technique in which the semen is directly deposited in the uterine cavity

Ovulation is synchronized by the administration of drugs to allow artificial insemination on predetermined days

Regularly checking of natural mating

Administration of drugs to synchronize estrus

Technique to promote superovulation by the administration of drugs to donor cows and transfer of the embryos to receptor cows

Employees trained to follow up and to assist calving when needed

Table 2 - Description of risk factors related to management practices in cow-calf production systems of southern Brazil

\begin{tabular}{ll}
\hline Factor that composes risk & $\begin{array}{l}\text { Direct costs involved in the application of a management practice, including inputs, labor, equipment, consulting, and } \\
\text { specific infrastructure }\end{array}$ \\
\hline Knost & $\begin{array}{l}\text { Knowledge level of the respondents on the application of a management practice } \\
\text { Difficulty level of implementing a management practice by farm workers, considering the existing infrastructure and } \\
\text { Operational complexity }\end{array}$ \\
Flexibility & Possibility of being replaced by other management practices that could yield similar results \\
\hline
\end{tabular}


Based on the scores assigned by the experts, the Risk (R) of each management practice was determined as:

$$
\mathrm{R}=\mathrm{C}+\mathrm{F}+\mathrm{OC}+\mathrm{K} \text {, }
$$

in which $\mathrm{C}$ is cost, $\mathrm{F}$ is flexibility, $\mathrm{OC}$ is operational complexity, and $\mathrm{K}$ is knowledge scores.

Due to the lack of consistent literature regarding the selected factors and to avoid influencing responses of experts, the same weight was applied to all factors. Considering that, depending on the analyzed variable, scores contribute differently to the equation, equivalence values were established (Table 3 ).

The calculated risk results were compared with the estimated risks using Williams' G-test and subjected to correlation analysis, considering association degrees higher than 0.70 as significant $(\mathrm{P}<0.05)$.

Table 3 - Equivalence values assigned to the dimensions included in the calculated risk equation

\begin{tabular}{lcc}
\hline & \multicolumn{2}{c}{ Equivalence value } \\
\cline { 2 - 3 } Score & $\begin{array}{c}\text { Cost, knowledge on the management practice, } \\
\text { and operational complexity }\end{array}$ & Flexibility \\
\hline 1 & 0.25 & 1.25 \\
2 & 0.50 & 1.00 \\
3 & 0.75 & 0.75 \\
4 & 1.00 & 0.50 \\
5 & 1.25 & 0.25 \\
\hline
\end{tabular}

\section{Results}

The estimated risk scores, based on the perception of experts, were affected by risk factors (Table 4). Operational complexity and cost had greater influence $(\mathrm{P}<0.01)$ on the estimated risks of nutritional, breeding, and general management practices. Furthermore, an increase in one unit in operational complexity and cost increased the risk by 0.43 and 0.28 points (maximum $=1$ point), respectively. The other factors did not significantly affect the estimated risk.

Relative to nutritional practices, the highest estimated risk score was observed for pasture irrigation, which, however, was not different from post- and pre-calving cow supplementation risk scores. Pasture irrigation was also associated to high operational complexity and low flexibility. The lowest estimated risk scores were given to creep-feeding and mineral supplementation, which were not different from each other.

In terms of general management practices, experts considered early weaning at 45-60 and at 60-90 days the most expensive, and no operational complexity risk score differences were detected among early weaning at 45-60, 60-90, and 90-120 days and for calf removal. Furthermore, greater estimated risk was obtained for early weaning at any age compared with the other practices.

The breeding practices superovulation and embryo transfer, artificial insemination, and fixed-time artificial insemination presented the highest cost and operational complexity scores.

When analyzing the average scores of management strategies, the highest cost score $(\mathrm{P}=0.001)$ was attributed to nutrition (3.5), followed by breeding (2.8) and management practices (2.1). Relative to average operational complexity scores, nutritional and breeding practices presented similar score (3.1), whereas a 2.8 score was obtained for general management. Higher average knowledge score was attributed to breeding practices (3.4), followed by nutritional (3.2) and general management (3.0); however, there was no statistical difference. Average flexibility scores $(\mathrm{P}>0.05)$ were similar between nutritional and general management (3.0), followed by breeding practices (2.8).

Estimated risk values were not different $(\mathrm{P}=0.07)$ from calculated risk values and were highly correlated $(\mathrm{r}=0.81)$, validating the method applied (Figure 1).

The calculated risk of general management technologies was the lowest, and no differences were detected between nutritional and breeding technologies. Input-dependent practices presented higher risk than process-related technologies (Table 5).

The lowest cost score was attributed to general management practices, while nutritional was considered more expensive than breeding practices. Process-related technologies were attributed lower cost scores than inputdependent technologies. The cost of pasture irrigation and superovulation/embryo transfer were considered very high, while the cost of $22 \%$ of the technologies was considered high, $28 \%$ average, and $44 \%$ low (Figure 2).

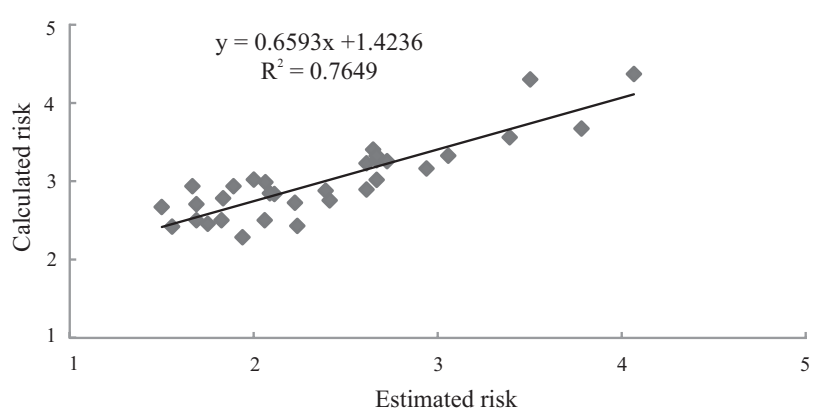

Figure 1 - Correlation between calculated risk scores and estimated risk scores of cow-calf management practices 
Relative to the need of technical knowledge, nutritional practice scores were not different from those obtained for general management and breeding practices. Processrelated technologies were considered less knowledgedemanding than input-dependent technologies. Overall, the experts considered that $22 \%$ of the management practices demand high technical knowledge, $75 \%$ require average knowledge, and only grouping cows according to calving date received low knowledge scores.

Operational complexity scores of breeding practices were not different compared with nutritional and general management practices. However, nutrition and breeding were considered more complex than management, and process-related technologies showed lower complexity when compared with those dependent on inputs. The other technologies were considered of high (9\%), average (69\%), and low complexity (19\%).

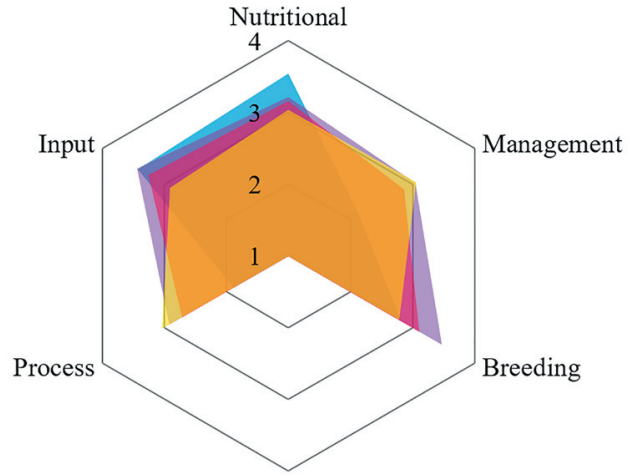

$\square$ Cost $\square$ Operational Complexity $\square$ Technical Knowledge $\square$ Flexibility

Figure 2 - Dimensions related to the risk of management practices to increase pregnancy rates of cow-calf production systems, according to their classification as nutritional, general management, and breeding practices, and as technologies depending on inputs or based on process innovations.

Table 4 - Average perceived risk scores and estimated risk of cow-calf management practices according to risk dimension ${ }^{1}$

\begin{tabular}{|c|c|c|c|c|c|}
\hline \multirow[b]{2}{*}{ Management practice } & \multicolumn{5}{|c|}{ Dimension } \\
\hline & Cost & $\begin{array}{l}\text { Operational } \\
\text { complexity }\end{array}$ & Knowledge & Flexibility & Estimated risk \\
\hline Nutritional & $3.5 \pm 0.6 \mathrm{~A}$ & $3.1 \pm 0.5$ & $3.2 \pm 0.3$ & $3.0 \pm 0.4$ & $2.5 \pm 0.5$ \\
\hline Creep-feeding & $3.0 \pm 0.9 \mathrm{ac}$ & $2.6 \pm 0.7 \mathrm{a}$ & $2.9 \pm 0.8 \mathrm{ab}$ & $3.2 \pm 0.9 \mathrm{ab}$ & $2.1 \pm 0.9 \mathrm{ac}$ \\
\hline Creep-grazing & $2.7 \pm 0.8 \mathrm{ac}$ & $3.0 \pm 1.0 \mathrm{a}$ & $2.7 \pm 1.0 \mathrm{a}$ & $2.9 \pm 1.0 \mathrm{ab}$ & $2.3 \pm 1.0 \mathrm{bc}$ \\
\hline Flushing & $3.6 \pm 0.9 \mathrm{ac}$ & $3.0 \pm 0.8 \mathrm{a}$ & $3.2 \pm 0.9 \mathrm{ab}$ & $3.0 \pm 0.9 \mathrm{ab}$ & $2.6 \pm 1.0 \mathrm{bc}$ \\
\hline Pasture irrigation & $4.8 \pm 0.3 b$ & $4.5 \pm 0.6 b$ & $4.0 \pm 1.3 b$ & $2.2 \pm 1.0 \mathrm{~b}$ & $3.5 \pm 1.2 \mathrm{~b}$ \\
\hline Improved pastures during postpartum period & $3.6 \pm 0.6 \mathrm{ac}$ & $3.2 \pm 0.8 \mathrm{a}$ & $3.2 \pm 1.0 \mathrm{ab}$ & $2.9 \pm 1.0 \mathrm{ab}$ & $2.6 \pm 0.9 b c$ \\
\hline Improved pastures pre-calving & $3.5 \pm 0.7 \mathrm{ac}$ & $3.1 \pm 0.8 \mathrm{a}$ & $3.3 \pm 1.0 \mathrm{ab}$ & $2.9 \pm 0.9 \mathrm{ab}$ & $2.7 \pm 1.0 \mathrm{bc}$ \\
\hline Hay supplementation & $3.2 \pm 1.0 \mathrm{ac}$ & $3.2 \pm 1.2 \mathrm{a}$ & $3.1 \pm 1.0 \mathrm{ab}$ & $3.5 \pm 0.5 \mathrm{a}$ & $2.0 \pm 0.7 \mathrm{bc}$ \\
\hline Cow supplementation post-calving & $3.9 \pm 1.1 \mathrm{bc}$ & $3.3 \pm 1.0 \mathrm{a}$ & $3.3 \pm 1.0 \mathrm{ab}$ & $3.0 \pm 0.9 \mathrm{ab}$ & $2.6 \pm 1.3 b c$ \\
\hline Cow supplementation pre-calving & $3.8 \pm 1.2 \mathrm{bc}$ & $3.2 \pm 0.9 \mathrm{a}$ & $3.3 \pm 1.0 \mathrm{ab}$ & $3.2 \pm 0.9 \mathrm{ab}$ & $2.6 \pm 1.3 b c$ \\
\hline Mineral supplementation & $3.0 \pm 0.9 \mathrm{ac}$ & $2.4 \pm 0.7 \mathrm{a}$ & $2.9 \pm 0.9 \mathrm{ab}$ & $3.3 \pm 1.1 \mathrm{ab}$ & $1.8 \pm 1.0 \mathrm{ac}$ \\
\hline General & $2.1 \pm 0.7 \mathrm{~B}$ & $2.8 \pm 0.5$ & $3.0 \pm 0.4$ & $3.0 \pm 0.3$ & $2.1 \pm 0.6$ \\
\hline Early weaning at 45-60 days & $3.8 \pm 1.2 \mathrm{bd}$ & $4.0 \pm 1.2 b$ & $3.7 \pm 1.3 \mathrm{a}$ & $2.9 \pm 1.0 \mathrm{a}$ & $3.8 \pm 1.0 \mathrm{~b}$ \\
\hline Early weaning at $60-90$ days & $3.4 \pm 1.2 \mathrm{bcd}$ & $3.6 \pm 1.1 b c$ & $3.2 \pm 1.1 \mathrm{ab}$ & $3.0 \pm 0.8 \mathrm{a}$ & $3.0 \pm 1.0 \mathrm{bc}$ \\
\hline Early weaning at 90-120 days & $2.6 \pm 0.8 \mathrm{ad}$ & $2.9 \pm 0.8 \mathrm{ab}$ & $3.1 \pm 0.8 \mathrm{ab}$ & $3.0 \pm 0.7 \mathrm{a}$ & $2.6 \pm 1.1 \mathrm{ab}$ \\
\hline Calf removal & $1.8 \pm 0.7 \mathrm{a}$ & $2.8 \pm 1.2 \mathrm{ab}$ & $2.6 \pm 1.0 \mathrm{ab}$ & $3.5 \pm 0.8 \mathrm{a}$ & $2.2 \pm 0.8 \mathrm{ac}$ \\
\hline Stocking rate adjusted according to body condition score & $1.6 \pm 0.8 \mathrm{a}$ & $2.9 \pm 1.3 \mathrm{ab}$ & $3.2 \pm 1.2 \mathrm{ab}$ & $3.2 \pm 0.9 \mathrm{a}$ & $1.5 \pm 0.5 \mathrm{a}$ \\
\hline Cow grouping according to its age & $1.7 \pm 0.9 \mathrm{a}$ & $2.9 \pm 0.8 \mathrm{ab}$ & $2.6 \pm 1.0 \mathrm{~b}$ & $3.2 \pm 1.1 \mathrm{a}$ & $1.7 \pm 0.8 \mathrm{a}$ \\
\hline Cow grouping by calving date & $1.5 \pm 0.7 \mathrm{a}$ & $2.9 \pm 1.0 \mathrm{ab}$ & $2.4 \pm 0.9 \mathrm{ab}$ & $3.3 \pm 1.0 \mathrm{a}$ & $1.5 \pm 0.7 \mathrm{a}$ \\
\hline Health plan & $2.1 \pm 1.1 \mathrm{ac}$ & $2.4 \pm 1.1 \mathrm{a}$ & $3.5 \pm 1.2 \mathrm{ab}$ & $2.7 \pm 1.1 \mathrm{a}$ & $2.1 \pm 1.1 \mathrm{ac}$ \\
\hline Culling of empty cows & $1.6 \pm 0.8 \mathrm{a}$ & $1.8 \pm 0.8 \mathrm{a}$ & $2.7 \pm 1.0 \mathrm{ab}$ & $3.0 \pm 1.4 \mathrm{a}$ & $1.9 \pm 0.9 \mathrm{ac}$ \\
\hline Pregnancy diagnosis & $1.8 \pm 0.7 \mathrm{a}$ & $2.4 \pm 1.0 \mathrm{ac}$ & $3.2 \pm 1.1 \mathrm{ab}$ & $2.7 \pm 1.2 \mathrm{a}$ & $1.7 \pm 0.9 \mathrm{a}$ \\
\hline Breeding & $2.8 \pm 1.0 \mathrm{AB}$ & $3.1 \pm 0.6$ & $3.4 \pm 0.6$ & $2.8 \pm 0.4$ & $2.6 \pm 0.8$ \\
\hline First mating at 18 months & $2.9 \pm 1.0 \mathrm{ac}$ & $3.0 \pm 1.2 \mathrm{ac}$ & $3.4 \pm 1.0 \mathrm{ab}$ & $3.3 \pm 1.1 \mathrm{a}$ & $2.6 \pm 1.1 \mathrm{ab}$ \\
\hline Biostimulation (cows) & $2.3 \pm 1.3 \mathrm{a}$ & $2.8 \pm 1.1 \mathrm{ac}$ & $2.9 \pm 1.1 \mathrm{ac}$ & $3.0 \pm 0.7 \mathrm{ab}$ & $2.4 \pm 1.4 \mathrm{ad}$ \\
\hline Soundness examination of bulls & $1.8 \pm 0.7 \mathrm{a}$ & $2.3 \pm 0.8 \mathrm{a}$ & $3.8 \pm 1.1 \mathrm{bc}$ & $2.2 \pm 1.1 \mathrm{ab}$ & $1.6 \pm 0.8 \mathrm{a}$ \\
\hline Artificial insemination & $3.2 \pm 0.8 \mathrm{bc}$ & $3.0 \pm 0.8 b c$ & $2.4 \pm 0.6 b c$ & $3.7 \pm 1.1 \mathrm{ab}$ & $2.9 \pm 0.7 \mathrm{bd}$ \\
\hline Fixed-time artificial insemination & $3.7 \pm 0.9 \mathrm{bc}$ & $3.4 \pm 0.8 \mathrm{bc}$ & $3.9 \pm 0.8 b c$ & $2.8 \pm 1.2 \mathrm{ab}$ & $3.4 \pm 0.8 \mathrm{bd}$ \\
\hline Mating monitoring & $1.8 \pm 0.7 \mathrm{a}$ & $2.8 \pm 1.0 \mathrm{ac}$ & $2.5 \pm 0.9 \mathrm{a}$ & $3.1 \pm 1.0 \mathrm{ab}$ & $1.8 \pm 0.7 \mathrm{ac}$ \\
\hline Estrus synchronization & $2.8 \pm 0.8 \mathrm{ac}$ & $3.2 \pm 0.8 \mathrm{ac}$ & $3.6 \pm 0.7 \mathrm{ab}$ & $3.0 \pm 0.8 \mathrm{ab}$ & $2.9 \pm 0.7 \mathrm{bcd}$ \\
\hline Superovulation and embryo transfer & $4.7 \pm 0.6 b$ & $4.4 \pm 0.9 b$ & $4.4 \pm 1.2 b$ & $2.1 \pm 1.0 \mathrm{~b}$ & $4.0 \pm 0.9 b$ \\
\hline Employee training in calving assistance & $2.4 \pm 0.7 \mathrm{a}$ & $2.8 \pm 0.9 \mathrm{ac}$ & $3.1 \pm 1.0 \mathrm{ac}$ & $2.6 \pm 1.0 \mathrm{ab}$ & $1.8 \pm 0.6 \mathrm{ac}$ \\
\hline
\end{tabular}

${ }^{1}$ Means for the answers according to a five-level Likert scale $(1=$ very low, 2 = low, $3=$ average, $4=$ high, $5=$ very high).

$\mathrm{a}, \mathrm{b}$ - Means followed by different lowercase letters in the column, differ by the Mann-Whitney's test $(\mathrm{P}<0.05)$.

A,B - Means followed by different uppercase letters in the column, differ by the Kruskal-Wallis test $(\mathrm{P}<0.05)$. 
Table 5 - Calculated risks of different dimensions of management practices applied to increase pregnancy rate of cow-calf production systems

\begin{tabular}{lcc}
\hline $\begin{array}{l}\text { Management practice } \\
\text { classification }\end{array}$ & Calculated risk $^{1}$ & Standard deviation \\
\hline Function & & \\
$\quad$ General management & $2.743 \mathrm{x}$ & 0.384 \\
Nutritional & $3.221 \mathrm{y}$ & 0.576 \\
Breeding & $3.150 \mathrm{y}$ & 0.436 \\
Type & & \\
$\quad$ Input-dependent & $3.303 \mathrm{a}$ & 0.460 \\
Process-related & $2.619 \mathrm{~b}$ & 0.209 \\
\hline
\end{tabular}

${ }^{1}$ Scores followed by the same superscripts are not different $(\mathrm{P}<0.05)$.

The flexibility factor presented no difference among the management practices, regardless of their type or function. High flexibility was identified for hay supplementation, calf removal, and two mating seasons per year. The other technologies were considered to have average flexibility $(81 \%)$, and pasture irrigation, soundness examination of bulls, and superovulation/embryo transfer, low flexibility.

\section{Discussion}

This study proposes a combination of empirical perceptions commonly applied for decision-making by farmers (Marques et al., 2011) with a rational and documentable method. Although this method was validated in the present study, a guide to assist farmers to consistently quantify the scores should be developed. Moreover, although these results contribute to the understanding of some management practices and may enhance their adoption rate, this study did not include typical questions, such as why some superior technologies have stalled and what factors could affect the willingness of farmers to adopt them (Leeuwis and Van den Ban, 2004; Borges et al., 2016).

In this context, this study offers a simple method that could be applied as tool for decision-making by farmer managers, technical consultants, and farmers associations, and improve the experience with the adoption of technologies. The use of this tool could expand the efficiency and profitability of cow-calf systems, reducing costs and increase the net margin of this firms.

As expected, innovative technologies, such as superovulation, embryo transfer, and early weaning, were considered the riskiest, perhaps due to the lack of knowledge and their high costs, which increase both their operational complexity and the distrust of farmers as to their results (Oaigen et al., 2008).

The concerns detected in this study regarding the cost of management practices were also observed by other authors (Rogers, 1995; Mugnier et al., 2012), highlighting the importance of cost in beef production, and may explain its significant effect on risk perceptions. This is especially evident in cow-calf systems, in which low profitability causes farmers to fear changes in their strategic routine. When facing natural or financial limitations, technologies with clear cost-efficiency are more easily adopted (Rapeya et al., 2001) and preferred by cow-calf farmers (Mugnier et al., 2012). The importance of cost may be related to the familiarity of farmers with this factor, as it must be taken into consideration daily, in almost every decision made, differently from flexibility. Furthermore, there is an additional cost related to new technologies, which is the access to information.

The relevance of operational complexity reflects the observations of other studies that identified that simple technologies are the most widespread (Denis et al., 2002). Operational complexity was also discussed by Rogers (1995), who highlighted the possibility of testing the technology on a small scale on the farm, and of foreseeing its results as factors that contribute to the adoption of a technology. Complexity can be reduced by performing field trials and presentations, contributing to the broadcast of consolidated strategies. Besides, when a technology is widespread, it can be used in a variety of situations, increasing its reliability (Weisenfelda and Ottb, 2011). In addition, the exchange of experiences and information may minimize the perception of operational complexity and contribute to the adoption of new technologies (Carruthers and Vanclay, 2012). However, in general, farm managers lack sufficient organization and interest to exchange ideas and experiences (Marques et al., 2011).

Although technical knowledge did not influence the perceived risk in this study, according to the experts, the knowledge on a specific technology seems to enhance its dissemination (Valente, 1996) and is related to the capacity to adapt it to new challenges. A complicating factor is the limited access to knowledge (Marques et al., 2011), as there are limited rural extension services for diffusion of new technologies in Brazil, compromising the competitiveness of Brazilian cow-calf systems. Furthermore, flexibility, which also had no influence on the estimated risk, is one of the most important factors of a competitive strategy (Hayes and Wheelwright, 1984), since the impossibility of replacing a technology with another in case of an unforeseen event, is extremely risky.

Although the proposed method is an interesting tool to support decision-making, risk perceptions are based upon incomplete information and are influenced by new information, individual beliefs, and local culture and 
traditions. Therefore, the results of its application may vary among individuals and over time (Weisenfelda and Ottb, 2011). Another relevant discussion is related to the acceptance of new technologies by consumers, who show an upward trend for low levels of innovation acceptance (Barcellos et al., 2010). Therefore, investments in the newest innovations may pose as a hidden risk and should be made considering the results of in-depth analyses of consumer trends and demands.

Nevertheless, productivity is considered as of the basis for sustainable food production when resources are limited (Godfray et al., 2010; Foley et al., 2011); as this is the case of many food production systems, the use of the proposed method could motivate the use of technologies and the overall productivity in cow-calf production systems. In general, higher productivity may be achieved by applying current technologies (Lobell et al., 2009) and management practices. This issue is central to the Brazilian beef production, demanding the closure of the yield gap, with the recovery of degraded pastures and avoiding production inefficiencies, instead of damaging new areas. However, adding value to a commodity based on socioeconomic and/or environment concerns is difficult to validate and to certify, since those are intangible assets.

Furthermore, management practices should be selected considering the context in which they will be inserted and the goals of the farmer. In Brazil, farmers use technologies because they believe they work or because they see others using it, but find it difficult to evaluate their cost-effectiveness (Barcellos et al., 2011). Moreover, farmers are often driven by the wish to remain updated and competitive, which may lead them to apply the most innovative technologies and solutions, instead of dealing with simple farm inefficiencies that could be easily eliminated.

Overall, we believe that the application of new nutritional, management, and breeding practices in cowcalf systems should be preceded by a preliminary risk assessment according to each factor proposed in the present study (cost, operational complexity, knowledge on the management practice, and flexibility). This will allow farmers to make focused and better-informed decisions on the management practices they wish to adopt, incurring in lower risks.

\section{Conclusions}

The risk assessment based on the four factors proposed in this study allowed determining which management practices are riskier in cow-calf systems, as perceived by experts. The operational complexity and implementation cost factors have the strongest influence on the risk of adopting such practices. Despite their importance, technical knowledge and flexibility were not valued by the experts in the decision-making models.

Farm managers and technical consultants may use the results of this study to identify, among the management practices evaluated, those that may result in higher uncertainties in their production model and those that may increase pregnancy rates of their herds.

This study proposed a simple method to assist farmers in the decision-making process of choosing the best technology or management practice to improve pregnancy rate in their systems. This analytical tool should be applied by farmers and technical consultants in real conditions to identify other opportunities and constraints of its use.

\section{Acknowledgments}

The financial support of the Conselho Nacional de Desenvolvimento Científico e Tecnológico (CNPq) is gratefully acknowledged.

\section{References}

Ayres, M.; Ayres, D. L. and Santos, A. L. 2007. BIOESTAT 5.0 Aplicações estatísticas nas áreas das ciências biológicas e da saúde. Instituto de Desenvolvimento Sustentável Mamirauá IDSM/MCT/CNPq, Belém.

ANUALPEC. Anuário da Pecuária de Corte. 2015. Agra FNP, São Paulo. 407p.

Barcellos, J. O. J.; Queiroz Filho, L. A.; Ceolin, A. C.; Gianezini, M.; McManus, C.; Malafaia, G. C. and Oaigen, R. P. 2011. Technological innovation and entrepreneurship in animal production. Revista Brasileira de Zootecnia 40:189-200.

Barcellos, M. D.; Kügler, J. O.; Grunert, K. G.; Wezemael, L. V.; Pérez-Cueto, F. J. A. and Verbeke, W. U. 2010. European consumers' acceptance of beef processing technologies: A focus group study. Innovative Food Science and Emerging Technologies $11: 721-732$.

Borges, J. A. R.; Tauer, L. W. and Oude Lansink, A. G. J. M. 2016. Using the theory of planned behavior to identify key beliefs underlying Brazilian cattle farmers' intention to use improved natural grassland: A MIMIC modelling approach. Land Use Policy 55:193-203. https://doi.org/10.1016/j.landusepol.2016.04.004

Burns, B. M.; Fordyce, G. and Holroyd, R. G. 2010. A review of factors that impact on the capacity of beef cattle females to conceive, maintain a pregnancy and wean a calf - Implications for reproductive efficiency in northern Australia. Animal Reproduction Science 122:1-22. https://doi.org/10.1016/j.anireprosci.2010.04.010

Carruthers, G. and Vanclay, F. 2012. The intrinsic features of Environmental Management Systems that facilitate adoption and encourage innovation in primary industries. Journal of Environmental Management 110:125-134. https://doi.org/10.1016/ j.jenvman.2012.06.003 
Cooper, D. R. and Schindler, P. S. 2014. Business research methods. 12th ed. McGraw-Hill, New York, USA.

Denis, J. L.; Hebert, A. Y.; Langley, D.; Lozeau, D. and Trottier, L. H. 2002. Explaining diffusion patterns for complex health care innovations. Health Care Management Review 27:60-73.

Dick, M.; Silva, M. A. and Dewes, H. 2015. Life cycle assessment of beef cattle production in two typical grassland systems of southern Brazil. Journal of Cleaner Production 96:426-434. https://doi.org/10.1016/j.jclepro.2014.01.080

Dill, M. D.; Emvalomatis, G.; Saatkamp, H.; Rossi, J. A.; Pereira, G. R. and Barcellos, J. O. J. 2015b. Factors affecting adoption of economic management practices in beef cattle production in Rio Grande do Sul state, Brazil. Journal of Rural Studies 42:21-28. https://doi.org/10.1016/j.jrurstud.2015.09.004

Dill, M. D.; Pereira, G. R.; Costa Jr., J. B. G.; Canellas, L. C.; Peripolli, V.; Braccini Neto, J.; Santanna, D. M.; McManus, C. and Barcellos, J. O. J. 2015a. Technologies that affect the weaning rate in beef cattle production systems. Tropical Animal Health and Production 47:1255-1260. https://doi.org/10.1007/s11250015-0856-x

Foley, J. A.: Ramankutty, N.; Brauman, K. A.; Cassidy, E. S.; Gerber, J. S.; Johnston, M.; Mueller, N. D.; O’Connell, C.; Ray, D. K.; West, P. C.; Balzer, C.; Bennett, E. M.; Carpenter, S. R.; Hill, J.; Monfreda, C.; Polasky, S.; Rockström, J.; Sheehan, J.; Siebert, S.; Tilman, D. and Zaks, D. P. M. 2011. Solutions for a cultivated planet. Nature 478:337-342. https://doi.org/10.1038/nature10452

Godfray, H. C. J.; Beddington, J. R.; Crute, I. R.; Haddad, L.; Lawrence, D.; Muir, J. F.; Pretty, J.; Robinson, S.; Thomas, S. M. and Toulmin, C. 2010 . Food security: the challenge of feeding 9 billion people. Science 327:812-818. https://doi.org/10.1126/science.1185383

Hayes, R. H. and Wheelwright, S. C. 1984. Restoring our Competitive Edge: Competing through manufacturing. New York, USA.

Johnson, R. J.; Doye, D.; Lalman, D. L.; Peel, D. S.; Raper, K. C. and Chung, C. 2010. Factors affecting adoption of recommended management practices in stocker cattle production. Journal of Agricultural Applied Economics 42:15-30. https://doi.org/10.1017/ S1074070800003266
Knight, F. H. 1921. Risk, Uncertainty and Profit. New York, USA.

Leeuwis, C. and Van den Ban, A. W. 2004. Communication for Rural Innovation: Rethinking Agricultural Extension. Wiley-Blackwell, Oxford, Oxfordshire, UK.

Lobell, D. B.; Cassman, K. G. and Field, C. B. 2009. Crop yield gaps: their importance, magnitudes, and causes. Annual Review of Environment Resources 34:179-204. https://doi.org/10.1146/ annurev.environ.041008.093740

Marques, P. R.; Barcellos, J. O. J.; McManus, C.; Oaigen, R. P.; Collares, F. C.; Canozzi, M. E. A. and Lampert, V. N. 2011. Competitiveness of beef farming in Rio Grande do Sul State, Brazil. Agricultural Systems 104:689-693.

Mugnier, S.; Magne, M. A.; Pailleux, J. Y.; Poupart, S. and Ingrand, S. 2012. Management priorities of livestock farmers: A ranking system to support advice. Livestock Science 144:181-189. https://doi.org/ 10.1016/j.livsci.2011.11.013

Oaigen, R. P.; Barcellos, J. O. J.; Christofari, L. F.; Braccini Neto, J.; Oliveira, T. E. and Prates, E. R. 2008. Melhoria organizacional na produção de bezerros de corte a partir dos centros de custos. Revista Brasileira de Zootecnia 37:580-587. https://doi.org/ 10.1590/S1516-35982008000300025

Purdy, G. 2010. ISO 31000:2009-Setting a new standard for risk management. Risk Analysis: An International Journal 30:881-886. https://doi.org/10.1111/j.1539-6924.2010.01442.x

Rapeya, H.; Lifranb, R. and Valadierc, A. 2001. Identifying social, economic and technical determinants of silvopastoral practices in temperate uplands: results of a survey in the Massif Central region of France. Agricultural Systems 69:119-135. https://doi.org/ 10.1016/S0308-521X(01)00021-X

Rogers, E. M. 1995. Diffusion of Innovations. Free Pre'ss, New York, USA.

Valente, T. W. 1996. Social network thresholds in the diffusion of innovations. Social Networks 18:69-89. https://doi.org/10.1016/ 0378-8733(95)00256-1

Weisenfeld, U. and Ott, I. 2011. Academic discipline and risk perception of technologies: An empirical study. Research Policy 40:487-499. https://doi.org/10.1016/j.respol.2010.12.003 